\title{
Scandilux-samarbejdet og vesteuropæisk sikkerhedspolitik
}

\begin{abstract}
En af de mere spandende nyudviklinger i vesteuropaisk sikkerhedspolitik i de senere âr er oprettelsen af Scandilux, et samarbejdsforum for de nordeuropaiske NATO-landes socialdemokratier. Scandilux placeres indledningsvis i forhold til den generelle tendens $i$ retning af transnationalisme $i$ vesteuropeisk politik. Dernast behandles samarbejdets karakter, dets hidtidige udvikling og dets indflydelse pâ de enkelte partier. Et sarligt afsnit analyserer Scandilux-samarbejdets betydning for de seneste års andringer $\mathrm{i}$ det danske socialdemokratis sikkerhedspolitik. Artiklen afsluttes med en diskussion af samarbejdets fremtid og dets muligheder for at udvikle et falles sikkerhedspolitisk perspektiv for de socialdemokratiske partier i Nordeuropa.
\end{abstract}

\section{Indledning ${ }^{1}$}

Scandilux er betegnelsen for et diskussionsforum for sikkerheds- og nedrustningspolitiske spørgsmål, som i 1981 oprettedes af de socialdemokratiske partier i de små nordeuropæiske NATO-lande. ${ }^{2}$ Scandilux har af seks "medlemspartier", det flamsk-belgiske Socialistische Partij (BSP), det wallonsk-belgiske Parti Socialiste (PSB), det hollandske Partij van de Arbeid (PvdA), det luxembourgske Letzeburger Arbechter Partei/Parti Ouvrier Socialiste Luxembourgeois, det danske Socialdemokratiet og Det norske Arbeiderparti (DNA). Desuden deltager tre større partier, det franske Parti Socialiste (PS), det britiske Labour Party og det vesttyske Sozialdemokratische Partei Deutschlands (SPD) i gruppens møder på observatørbasis.

Oprettelsen af Scandilux afspejler en bred transnational tendens i vesteuropæisk politik, der har taget fart $\mathrm{i}$ efterkrigstiden parallelt med udvidelsen af det internationale samarbejde. Politiske partier, interesseorganisationer ${ }^{3}$ og de nye græsrodsbevægelser interesserer sig i stigende grad for de tværnationale aspekter af deres virksomhed og knytter kontakter til tilsvarende organisationer $\mathrm{i}$ andre lande, og disse kontakter afspejler sig stadig mere i deres aktivitet på nationalt plan. Det er ikke blot forretningslivet, som er blevet internationaliseret, det er også i høj grad det politiske liv. Derfor, som Geoffrey og Pippa Pridham fremhæver $\mathrm{i}$ deres studie af partisamarbejde og europæisk integration, "transnational party cooperation can no longer be considered purely at its horizontal level as a European exercise, but must also be examined vertically with respect to the impact of national party outlooks ... on such European level activity as well as the possible influence of the latter on the former". ${ }^{4}$

Denne artikel tager udgangspunkt $i$ en diskussion af Scandilux som en europæisk "exercise" i form af en gennemgang af gruppens historie og specifikke karakteristika; dernæst analyseres den gensidige påvirkning mellem gruppen og de enkel- 


\title{
Scandilux-samarbejdet og vesteuropæisk sikkerhedspolitik
}

\begin{abstract}
En af de mere spandende nyudviklinger i vesteuropaisk sikkerhedspolitik i de senere âr er oprettelsen af Scandilux, et samarbejdsforum for de nordeuropaiske NATO-landes socialdemokratier. Scandilux placeres indledningsvis i forhold til den generelle tendens $i$ retning af transnationalisme $i$ vesteuropeisk politik. Dernast behandles samarbejdets karakter, dets hidtidige udvikling og dets indflydelse pâ de enkelte partier. Et sarligt afsnit analyserer Scandilux-samarbejdets betydning for de seneste års andringer $\mathrm{i}$ det danske socialdemokratis sikkerhedspolitik. Artiklen afsluttes med en diskussion af samarbejdets fremtid og dets muligheder for at udvikle et falles sikkerhedspolitisk perspektiv for de socialdemokratiske partier i Nordeuropa.
\end{abstract}

\section{Indledning ${ }^{1}$}

Scandilux er betegnelsen for et diskussionsforum for sikkerheds- og nedrustningspolitiske spørgsmål, som i 1981 oprettedes af de socialdemokratiske partier i de små nordeuropæiske NATO-lande. ${ }^{2}$ Scandilux har af seks "medlemspartier", det flamsk-belgiske Socialistische Partij (BSP), det wallonsk-belgiske Parti Socialiste (PSB), det hollandske Partij van de Arbeid (PvdA), det luxembourgske Letzeburger Arbechter Partei/Parti Ouvrier Socialiste Luxembourgeois, det danske Socialdemokratiet og Det norske Arbeiderparti (DNA). Desuden deltager tre større partier, det franske Parti Socialiste (PS), det britiske Labour Party og det vesttyske Sozialdemokratische Partei Deutschlands (SPD) i gruppens møder på observatørbasis.

Oprettelsen af Scandilux afspejler en bred transnational tendens i vesteuropæisk politik, der har taget fart $\mathrm{i}$ efterkrigstiden parallelt med udvidelsen af det internationale samarbejde. Politiske partier, interesseorganisationer ${ }^{3}$ og de nye græsrodsbevægelser interesserer sig i stigende grad for de tværnationale aspekter af deres virksomhed og knytter kontakter til tilsvarende organisationer $\mathrm{i}$ andre lande, og disse kontakter afspejler sig stadig mere i deres aktivitet på nationalt plan. Det er ikke blot forretningslivet, som er blevet internationaliseret, det er også i høj grad det politiske liv. Derfor, som Geoffrey og Pippa Pridham fremhæver $\mathrm{i}$ deres studie af partisamarbejde og europæisk integration, "transnational party cooperation can no longer be considered purely at its horizontal level as a European exercise, but must also be examined vertically with respect to the impact of national party outlooks ... on such European level activity as well as the possible influence of the latter on the former". ${ }^{4}$

Denne artikel tager udgangspunkt $i$ en diskussion af Scandilux som en europæisk "exercise" i form af en gennemgang af gruppens historie og specifikke karakteristika; dernæst analyseres den gensidige påvirkning mellem gruppen og de enkel- 
te partier, dvs. både internationaliseringen af de enkelte partiers sikkerhedspolitik og deres internalisering af den "politik", der udvikles i Scandilux-samarbejdet, og endelig diskuteres udsigterne for dettes fremtid.

Det måske mest iøjnefaldende træk ved Scandilux-samarbejdet er dets uformelle karakter. Som det vil fremgå, er der mange fordele knyttet hertil, men der er samtidig den ulempe set ud fra et forskningsmæssigt synspunkt, at samarbejdet aflejrer meget lidt materiale, både internt og eksternt. Denne analyse har derfor $\mathrm{i}$ udstrakt grad gjort brug af interviews med de faste deltagere i Scandilux-møderne; ialt er 16 deltagere representerende 7 af Scandilux' 9 partier blevet interviewet. ${ }^{5}$ Derudover er forskelligt sikkerhedspolitisk materiale fra de deltagende partier blevet inddraget $\mathrm{i}$ analysen.

\section{Scandilux: Den generelle baggrund}

Som det senere vil fremgå, havde oprettelsen af Scandilux baggrund i de særlige problemer, som de socialdemokratiske partier i de mindre NATO-lande stod overfor i vinteren 1980-81. Men der er også en bredere baggrund for Scandilux, som må inddrages i analysen, og som blandt andet består af den socialdemokratiske tradition for transnationalt samarbejde. De enkelte socialdemokratiske partier har fra deres oprettelse i sidste århundrede opfattet sig som dele af en bredere arbejderbevægelse tværs over de nationale grænser, hvis mål ikke blot har været arbejderklassens økonomiske, sociale og politiske fremgang, men også fremme af international fred og forståelse. Erfaringer fra de to verdenskrige, som det ikke lykkedes den internationale arbejderbevægelse at forhindre, og fra den delagtighed $\mathrm{i}$ magten, som de fleste partier efterhånden har opnået, har formentlig gjort de socialdemokratiske partier som helhed mere indadvendte, men alligevel har det internationale partisamarbejde hele tiden bevaret en fremtrædende plads i deres programmatiske og praktiske politik. Den voksende interdependens i det internationale system har i de seneste tiår ført til en kraftig vækst i de transnationale forbindelser, og denne tendens har givet samarbejdet mellem de socialdemokratiske partier en ny dynamik. Siden midten af 1970'erne har Socialistisk Internationale (S.I., oprettet 1951) således undergået en kraftig ekspansion; for det første har organisationen udvidet sin geografiske dækning ved at tiltrække en lang række medlems- og associerede partier fra den tredie verden, særlig Latinamerika, for det andet er der sket en udvidelse af dens politiske emneflade ved, at fred, sikkerhed og udvikling er blevet vigtige punkter på dens dagsorden, og endelig har S.I.s generelle aktivitetsniveau været stærkt stigende.

En anden afspejling af den transnationale tendens er oprettelsen af Confederation of the Socialist Parties of the European Community, som samler de socialdemokratiske partier i EF (med undtagelse af det græske PASOK) og ansøgerlandene, og som andre europæiske partier er knyttet til på observatørbasis.

Et andet væsentligt element $\mathrm{i}$ den generelle baggrund for Scandilux er den kraftige politisering af sikkerheds- og nedrustningsspørgsmål, der begyndte at gøre sig gældende overalt i Vesteuropa i slutningen af 1970'erne. Disse spørgsmål har spillet en væentlig rolle i den fornyelse af Socialistisk Internationale, der indledtes med valget af Willy Brandt til organisationens præsident i $1976 .{ }^{6}$ I sin 
indsattelsestale nævnte Brandt "en offensiv for en sikker fred" som den første af tre udfordringer. S.1. stod overfor. ${ }^{7}$ Siden da - og især efter nedsættelsen i 1978 af en nedrustningsstudiegruppe under ledelse af formanden for det finske socialdemokrati Kalevi Sorsa - har nedrustningsspørgsmål varet et af de vasentligste politiske emner i S.I. Gennem en møderække med amerikanske, sovjetiske og tredie verdens ledere har Sorsa-komitéen $s \emptyset \mathrm{gt}$ at etablere S.I. som en uafhængig aktør eller pressionsgruppe i international nedrustningspolitik. På S.I.s kongres $\mathrm{i}$ Madrid i november 1980 institutionaliseredes Sorsa-gruppen (Socialist International Disarmament and Arms Control Advisory Council: SIDAC), og dens rapport Peace in the 1980s and Beyond blev antaget som S.I.s officielle politik. I de seneste år har forskellige S.1.-organer udsendt en rakke stadig mere specifikke erklæringer og anbefalinger vedrørende internationale nedrustningsspørgsmål. Alligevel er det tvivlsomt, hvor baredygtig koncentrationen om sikkerhedspolitiske spørgsmål vil vare i det lange løb. Interessen for disse spørgsmål er stort set koncentreret til de nordeuropæiske partier; de sydeuropæiske (især det franske PS) er skeptiske over for den linie, som S.I. har fulgt, mens de ikke-europæiske partier stort set er uinteresserede i nedrustningsspørgsmål. Socialistisk Internationales ambitioner om at kunne lægge pres på supermagterne i spørgsmâlet er heller ikke blevet opfyldt. Frustrationer over S.I.s begrænsede muligheder hører således med til den generelle baggrund for Scandilux.

Den øgede interesse for sikkerhedspolitiske spørgsmål har også påvirket Konføderationen af socialdemokratiske partier i EF. Organisationen har sammen med det franske PS afholdt en konference om sikkerhed og nedrustning ${ }^{8}$ og nedsat en arbejdsgruppe om Europe's Place in the World. Men konføderationen er hæmmet af at være orienteret mod EFs aktiviteter og af, at spørgsmålet om EFs sikkerhedspolititiske rolle er stærkt omstridt i medlemspartierne. I 1979 lykkedes det ikke konføderationen at enes om et fælles manifest til EF-valget, især fordi Labour og det danske socialdemokrati fandt udkastet for integrationistisk. Disse to partier er også meget tøvende over for at diskutere, hvad der ofte refereres til som "de militære aspekter af europæisk integration".

Pă dette punkt erkender det vedtagne manifest til EF-valget i 1984, at "the EC has no competence in matters which are in the military field", ligesom det noterer medlemspartiernes erkendelse af "their disagreements on the role of nuclear weapons and nuclear deterrence for the security of Europe" - en henvisning til de klare sikkerhedspolitiskc uoverensstemmelser mellem de nordeuropæiske og sydeuropæiske partier i konføderationen. ${ }^{9}$ 1984-manifestet repræsenterer alligevel et forsigtigt skridt fremad i udviklingen af et sikkerhedspolitisk program for konføderationen ved at understrege behovet for, at Europa indtager en mere uafhængig position i øst-vest konfrontationen, og ved at opfordre EF til at øge sin beskæftigelse med "de politiske aspekter af europæisk sikkerhed". Dette er imidlertid grænsen for, hvor langt konføderationen kan gå i retning af sikkerhedspolitisk stillingtagen, og den har derfor kun været af begrænset nytte for formuleringen af en bredere sikkerhedspolitisk koncept som den, de mindre partier har fảet et behov for.

Endelig skal nævnes et tredie relevant udslag af den internationale politisering af sikkerhedspolitikken. Selv om de to såkaldt uafhængige kommissioner om 
nord-syd problemer og internationale nedrustnings- og sikkerhedsproblemer, der har været ledet af henholdsvis Willy Brandt og Olof Palme, ikke formelt har været socialdemokratiske foretagender, kan de alligevel placeres inden for den generelle tendens til at diskutere og formulere nye og mere markante sikkerhedspolitiske positioner, som karakteriserer mange socialdemokratiske partier i Vesteuropa. Det er således karakteristisk, at mange af Palme-kommissionens anbefalinger, herunder også det centrale begreb "common security", i de sidste par år er blevet optaget af disse partier - og ikke mindst af de partier, der samles i Scandiluxsamarbejdet. ${ }^{10}$

\section{Scandilux: Den specifikke baggrund}

I en mere snæver forstand skyldes oprettelsen af Scandilux specifikke interesser og behov hos partierne i de små NATO-lande, for hvem de eksisterende organisationer som S.I., inklusive SIDAC, eller konføderationen ikke var egnede fora. Da disse interesser og behov var nært knyttet til deres medlemskab af og roller $\mathrm{i}$ NATO, måtte der findes en ny ramme.

Scandilux er også en nydannelse i den forstand, at der praktisk taget ikke findes nogen tradition for samarbejde mellem Norden og Benelux, hverken på det statslige eller det partimæssige niveau. ${ }^{11}$ De socialdemokratiske partier $\mathrm{i}$ disse lande har som regel været mere orienteret mod at udvikle partirelationer til de større partier, dvs. SPD, PS og Labour, og samtidig videreudvikle de traditionelle regionale partimæssige forbindelser. De hollandske og belgiske partier har en lang tradition for samarbejde, og dette er i endnu højere grad tilfældet mellem partierne i Danmark og Norge, der dels har udviklet sig bilateralt, dels inden for en bredere fællesnordisk ramme, den såkaldte nordiske samarbejdskomité (SAMAK).

Tilskyndelsen til Scandilux skal derfor findes i udviklingen inden for NATO, der netop i slutningen af 1970'erne ændrede karakter i en retning, der skabte vanskeligheder for flere af de mindre partier. USA forstærkede kravet om en større europæisk indsats i NATO, både hvad angår burden-sharing, det vil sige deling af de økonomiske byrder ved NATO-forsvaret, og deltagelse i alliancebeslutninger. NATOs langtidsprogram (LTDP) af 1978 forøgede presset for $\emptyset$ gede forsvarsbevillinger $\mathrm{i}$ en situation, hvor økonomien $\mathrm{i}$ forvejen var anspændt på grund af voksende sociale udgifter i kølvandet af oliekrisen. Og både det mislykkede forsøg i 1977-78 på at træffe en fælles NATO-beslutning om neutronbomben og den gennemførte dobbeltbeslutning af december 1979 om at deployere mellemdistancemissiler i Vesteuropa syntes at presse de små lande og partier til at tage medansvar for beslutninger, som de kun havde ringe lyst til at deltage i, og som de ikke følte at have nogen reel indflydelse på.

Det senere samarbejdsmønster i Scandilux blev på en måde foregrebet $\mathrm{i}$ forbindelse med NATOs dobbeltbeslutning. I hvert fald de belgiske, hollandske og danske partier havde indgående konsultationer med SPD, der pressede kraftigt på for at få dem til at gå ind for beslutningen. Der var også en del indbyrdes konsultationer mellem de mindre partier, $\mathrm{i}$ hvert fald mellem de hollandske og belgiske, de hollandske og danske og de danske og norske partier. På grund af et intenst 
krydspres og manglende tid til koordinering endte de fire landes partier imidlertid på forskellige positioner. Det hollandske arbejderparti (PvdA), som på det tidspunkt var det eneste $\mathrm{i}$ opposition, og inden for hvilket politiseringen af sikkerhedspolitikken var slået igennem både tidligere og kraftigere end $\mathrm{i}$ andre partier, lagde sig fra begyndelsen fast på en modstand mod dobbeltbeslutningen, omend det ikke var helt klart, om denne var betinget eller absolut. Det danske socialdemokrati, som dannede en mindretalsregering i oktober 1979 efter SV-regeringens sammenbrud, var mere eller mindre uforberedt på dobbeltbeslutningen og endte - efter at have udsendt divergerende signaler - på et forslag om en 6 måneders udsættelse af beslutningen, mens forhandlingsmulighederne blev afprøvet over for Sovjetunionen. Til partiets skuffelse fandt forslaget ikke støtte hos de andre partier. Det norske Arbeiderparti havde nok været mere involveret $i$ forberedelserne af dobbeltbeslutningen end de andre partier og lå på det tidspunkt på en positiv linie, som først på et lidt senere tidspunkt blev til genstand for en ophidset intern debat. Imellem de danske og norske standpunkter lå de to belgiske partier, som på den ene side verbalt støttede dobbeltbeslutningen, men på den anden side ikke $\emptyset$ nskede at forpligte Belgien til at modtage de tiltænkte missiler, før forhandlingsbestræbelserne var ført til endc. Denne stillingtagen dækkede over væsentlige interne forskelle i og mellem partierne. Det wallonske PSB, hvis leder var udenrigsminister Henri Simonet, var noget mere positivt indstillet end det flamske BSP. Blandt de flamske socialister var der stor skepsis over for beslutningen, og senere kom de til at føle, at de var blevet manipuleret til at støtte den af udenrigsminister Simonet, blandt andet gennem de oplysninger denne havde givet om de $\emptyset$ vrige socialdemokratiers holdning.

Den manglende koordination omkring dobbeltbeslutningen blev det vigtigste motiv for oprettelsen af Scandilux et år senere. Initiativet til Scandilux blev taget $\mathrm{i}$ forbindelse med Socialistisk Internationales møde i Madrid i november 1980, hvor Karel van Miert fra BSP og Klaas de Vries fra PvdA sammen kom på ideen om at oprette et særligt forum for de mindre partier og blev mødt med en øjeblikkelig positiv respons på uformelle sondringer af delegerede fra andre partier. I løbet af de følgende uger udarbejdede repræsentanter for de to partier et idégrundlag for samarbejdet, ifølge hvilket delegationer fra de socialdemokratiske partier i de små NATO-lande skulle mødes regelmæssigt på informel basis for at informere hinanden om udviklingen i deres respektive lande og partier. På baggrund heraf udsendte de to belgiske partier en invitation til partierne i Holland, Luxembourg, Danmark og Norge til et indledende møde. ${ }^{12}$

Invitationen næunte ogsă andre problemomrăder end dobbeltbeslutningen; blandt andet henviste den til det accelererende våbenkapløb, den amerikanske afvisning af at ratificere SALT II- aftalen samt udsigterne til nye krav i NATO om forøgede forsvarsudgifter. "In this context, the role to be played by the smaller European countries should receive renewed attention. We may wish to avoid being faced with already prepared decisions by the major countries when consultation with the minor powers start in NATO".

Her dukker en anden, mere defensiv, målsætning for Scandilux frem, nemlig behovet for at de små partier kunne stive hinanden af over for det forventede pres fra den nyvalgte Reagan-administration. Alle partier var i vinteren 1980-81 be- 
kymrede over udsigterne til forøget international spænding og til forringede chancer for igangværende og kommende rustningskontrolforhandlinger. Scandiluxinitiativet skulle sikre, at også de små landes røst blev hørt i den forbindelse.

\section{Scandilux: En kort karakteristik}

Det første møde i Scandilux fandt sted i Amsterdam i januar 1981 med deltagelse fra de seks inviterede partier, det vil sige de to belgiske partier PSB og BSP, det luxembourgske parti, det hollandske PvdA og de norske og danske partier. Et af de umiddelbart mere overraskende beslutninger på mødet var at udvide deltagerkredsen ved at invitere repræsentanter for SPD og Labour til i fremtiden at deltage i møderne som observatører. Oprindelig blev Socialistisk Internationale også anmodet om at lade sig repræsentere, formentlig for at modvirke den frygt for, at Scandilux skulle opfattes som en konkurrent, som blandt andet de danske socialdemokrater nærede. ${ }^{13}$ S.I. blev dog ikke repræsenteret, sikkert fordi SPD's faste repræsentant, Egon Bahr, som mangeårig nær medarbejder af Willy Brandt $\mathrm{i}$ praksis varetager kontakten til Socialistisk Internationale. Derimod har repræsentanter for SPD og Labour deltaget regelmæssigt i Scandilux siden gruppens andet møde i Oslo i marts 1981. Efter Mitterands valg til fransk præsident i 1981 blev også det franske PS inviteret til at lade sig repræsentere.

Der synes at have været flere grunde til at invitere de større partier og specielt SPD med i gruppen. Den væsentligste var behovet for information, hvor SPD stod i en nøgleposition. Partiet var på dette tidspunkt endnu i regering og midt $i$ en meget aktiv diplomatisk bestræbelse for at få USA og Sovjetunionen til at indlede forhandlinger $\mathrm{i}$ INF-spørgsmålet; det havde derfor informationskilder, som ikke stod til rådighed for de mindre partier. Et ledsagende motiv var at forbedre de små partiers muligheder for indflydelse på den tyske politik i INF-spørgsmålet og derigennem på den internationale behandling af spørgsmålet. Endelig spillede "likemindedness"-motivet en rolle, det vil sige fornemmelsen af, at SPD i centrale sikkerhedspolitiske spørgsmål stod de mindre partier ret nær, og at et nærmere samarbejde også af den grund ville være hensigtsmæssigt.

Beslutningen om at invitere observatører var således velbegrundet og har aldrig været "fortrudt" af de små partier. På den anden side repræsenterede den en vis udvanding af den oprindelige idé med Scandilux som et forum for de små partier og åbnede en potentiel indflydelseskanal for SPD og - i hvert fald i teorien Labour og PS.

SPD's indflydelse på Scandilux har da også været ganske betydelig. Både som informationskilde og analytiker har Egon Bahr været en central skikkelse. I begyndelsen holdt SPD's repræsentanter en relativt lav profil i møderne af hensyntagen til de oprindelige medlemmer, men gradvis kom de til at deltage på lige fod med de små partiers repræsentanter i gruppens politiske diskussioner og endog til at spille en ledende rolle. I organisatoriske spørgsmål, såsom tilrettelæggelse af møder eller de løbende overvejelser over Scandilux' fremtidige form, holder SPD's repræsentanter stadig en lav profil. Som forum opfattes Scandilux stadig som de oprindelige seks partiers ansvar.

Labour- og PS-repræsentanternes adfærd har mere været i overensstemmelse 
med deres formelle observatørstatus. Labour har siden foråret 1981 været regelmæssigt repræsenteret ved Scandilux-møderne og lægger stor vægt på sin deltagelse, hvilket blandt andet fremgår af, at partiets delegation som regel har været ledet af partiformanden. først Michael Foot og nu Neil Kinnock. Labour har imidlertid i højere grad opfattet Scandilux som en bekvem lyttepost, hvor man kan følge med i udviklingen i de kontinentale partiers sikkerhedspolitik, snarere end som et forum for påvirkning af disse. Dette har sin baggrund $i$, at Labour - $i$ det mindste indtil det katastrofale valg i 1983 - har ligget på en sikkerhedspolitisk linie, der adskiller sig markant fra de andre partiers. ${ }^{1.4}$

Det franske socialistparti har endnu mere været en outsider i Scandilux. Det har som regel varet reprasenteret pă lavere niveau (international sekretær) end de $\emptyset$ vrige partier og har med sin divergerende politik i INF-spørgsmålet $\mathrm{i}$ forhold til disse med stigende skepsis fulgt diskussionen i Scandilux og specielt den rolle, som SPD har spillet i gruppen. Efter mødet i Bruxelles oktober 1983, hvor Scandilux besluttede at udsende en opfordring til at udsætte INF-deployeringen (se nedenfor), besluttede PS at boykotte yderligere møder i Scandilux. Partiet vendte dog tilbage til gruppen i marts $1984 \mathrm{i}$ forbindelse med en forbedring af forholdet til SPD. 15

Indtil nu har de fleste reprasenterede partier opfattet Scandilux som et velegnet og passende diskussionsforum. Bortset fra PS har kun det wallonske parti PSB (som traditionelt orienterer sig mod de franske socialister) haft reservationer vedrørende Scandilux' geografiske omfang og vist interesse for at udvide denne ramme med de sydeuropæiske partier, enten gennem fælles møder i S.I.-regie eller ved at inddrage EF-konføderationen. Sådanne forslag er blevet afvist af de $\emptyset$ vrige partier, ikke mindst af de nordiske, der er bange for, at en inddragelse af de sydeuropæiske partier vil true Scandilux' karakter af at være et forum for ligesindede partier. Der er dog nu udsigt til, at et portugisisk forslag om et fælles møde mellem Scandilux-partierne og de sydeuropæiske partier kan realiseres i løbet af 1985. Baggrunden herfor er en vis nervøsitet og jalousi over for Scandilux fra de sydeuropæiske partiers side, specielt de to italienske medlemmer af S.I., PSI og PSDI. I de seneste ăr har det traditionelle magtmønster inden for NATOEuropa skiftet dramatisk karakter: De traditionelt magtbærende socialdemokratier i nord er ét for ét blevet tvunget i opposition; ${ }^{16}$ til gengæld har Sydens evindelige oppositionspartier pludselig opnået regeringsmagten $\mathrm{i}$ deres respektive lande. ${ }^{17}$ Da disse partier - med undtagelse af det græske PASOK - samtidig er slået ind på en sikkerhedspolitisk linie, der ligger tæt på den traditionelle NATOkonsensus, er de i stigende grad blevet kritiske over for tendensen i Scandiluxsamarbejdet og over for, hvad de opfatter som de nordeuropæiske partiers dominerende indflydelse i S.I. Samtidig med at Scandilux har betydet meget for samarbejdet inden for sin egen kreds, har det også bidraget til at accentuere og måske forstærke modsætningerne mellem Nord- og Sydeuropa i den socialdemokratiske bevægelse. Dette har endog ført til forsøg på at oprette en sydeuropæisk pendant til Scandilux; forskellene imellem de deltagende partier fra Frankrig, Spanien, Portugal og Italien er dog væsentlig større end mellem de nordeuropæiske, og dette samarbejde skal derfor først og fremmest tillægges betydning som en reaktion på Scandilux. 


\section{Format $\mathrm{og}$ funktioner}

Siden januar 1981 har Scandilux holdt ialt 17 møder. Møderne er korte (under 1 døgns varighed), men diskussionen på dem er omfattende og intensiv, fordi der bruges meget lidt tid på proceduremæssige spørgsmål, og fordi deltagerne, en gruppe på 20-30, efterhånden kender hinanden godt. ${ }^{18}$ Indtil nu har det mest karakteristiske træk ved Scandilux været den næsten totale fravær af formel procedure. Møderne har ingen formel dagsorden, der tages ikke officielt referat, og der udsendes ikke communiquéer fra dem.

Denne mangel på formalitet må ikke tolkes som betydningsløshed. Tværtimod viser mødernes hyppighed og den regelmassighed, som ofte travle partiledere deltager $\mathrm{i}$ dem med, at deltagerne selv tillægger dem betydelig vægt. Efter adskillige deltageres udsagn er fordelen ved Scandilux netop fraværet af procedure og det manglende pres for at enes om konkrete politiske formuleringer, der gør det muligt at føre en fri og ubundet diskussion af aktuelle sikkerhedspolitiske problemer. I denne henseende sammenlignes Scandilux ofte positivt med Socialistisk Internationale, hvis arbejde netop er hæmmet af procedure og tidkrævende forhandlinger om formuleringer og kompromisser.

Scandilux har indtil nu haft tre hovedfunktioner: informationsudveksling, politisk diskussion og formulering af politikker. Informationsudveksling er den mindst kontroversielle af disse og samtidig formentlig den mest værdsatte, især af de mindre partier, der kun har begrænsede egne muligheder for at holde sig informeret om detaljerne i den internationale udvikling. Denne funktion er vokset $\mathrm{i}$ betydning, siden de mindre Scandilux-partier ét efter ét mistede regeringsmagten $\mathrm{i}$ deres lande og dermed også adgangen til regeringsbureaukratiernes informationsnet. I 1982 overgik dette også SPD, men på grund af partiets og Egon Bahrs "private" informationskanaler har det været i stand til fortsat at levere informationer af høj kvalitet om den internationale sikkerhedspolitiske udvikling. Egon Bahrs briefinger, som $\mathrm{i}$ høj grad er baseret på hans nære forbindelser med sovjetiske og østeuropæiske ledere samt med INF-forhandlerne i Geneve, har klart været det centrale element i Scandilux' funktion som "informationsbørs". Man skal imidlertid ikke af den grund undervurdere betydningen af de informationer, som også repræsentanter for de mindre partier kan levere. På grund af sprogbarrierer og en naturlig orientering mod de større partier, har de mindre partier været dårligt informeret om hinandens politik, selv om de ofte har stået $\mathrm{i}$ parallelle politiske situationer. Dette problem har Scandilux i vid udstrækning løst.

Den vigtigste funktion af Scandilux har imidlertid altid været diskussion af aktuelle sikkerhedspolitiske spørgsmål. Denne diskussion er ustruktureret i den forstand, at der indtil fornylig ikke har foreligget en dagsorden eller noget forud bestemt emne for møderne ud over "den aktuelle situation". Til det første møde udarbejdede værtspartiet PvdA en liste af mulige emner og spørgsmål, men denne praksis blev siden opgivet for først at blive taget op igen i slutningen af 1983 . Scandilux-diskussionerne har derfor $\mathrm{i}$ høj grad været ad hoc og improviserede. Mens denne praksis givetvis har gavnet diskussionsfriheden og muliggjort en fleksibel tilpasning til den hurtigt skiftende sikkerhedspolitiske udvikling, har den 
også medført en vis mangel på langtidsperspektiv i gruppens drøftelser. Nogle medlemspartier, for eksempel det flamske BSP og PvdA har derfor søgt at tilføre diskussionen et større mål af struktur og perspektiv ved at forelagge diverse policy-papers; for eksempel har Karel van Miert og Klaas de Vries ved en lejlighed fremlagt en diskussionstekst baseret på en seks-punkts plan udviklet inden for BSP; også andre partier har ved lejlighed præsenteret interne policy-papirer.

Diskussioner på dette grundlag har dog indtil videre mest haft en opklarende karakter, blandt andet fordi nogle partier, isæer det danske, men ogsă for eksempel SPD, har varet tøvende over for at gå videre end til uformelle diskussioner af aktuelle spørgsmål. Som begrundelse fremføres ofte, at diskussionerne vil blive formaliserede og sterile. hvis de centreres om bestemte tekster, men forskellene afspejler også forskelle i politisk kultur mellem partierne i Scandilux.

Disse forskelle afspejler samtidig også divergerende opfattelser af Scandilux' rolle som et policy-making forum. Ligesom Socialistisk Internationale er Scandilux baseret på forudsætningen om det enkelte partis autonomi; på grund af det interne partidemokrati kan beslutninger i internationale fora ikke binde det enkelte parti til en bestemt linie. Hidtil har Scandilux endda fulgt en mere strikt linie end S.I. ved helt at undlade at traffe beslutninger, vedtage resolutioner eller udsende communiquéer; det eneste offentlige "output" fra Scandilux er de pressekonferencer, som afslutter de fleste af møderne, og hvor en repræsentant for værtspartiet sammenfatter mødets diskussioner. Den eneste undtagelse fra dette billede var fremlæggelsen af et såkaldt pressekonference-dokument efter mødet $\mathrm{i}$ Bruxelles oktober 1983, hvori Scandilux-partierne relativt detaljeret fremlagde deres syn på INF-problematikken. Fra PS' side protesteredes der da også kraftigt mod denne fremgangsmåde, og også andre partier følte, at den lå på kanten af, hvad Scandilux kunne foretage sig som gruppe. PS har i det hele taget været stærkt kritisk over for enhver tendens til, at Scandilux skulle udvikle sig til et egentligt policy-making organ, da dette ville svække partiet ikke blot i selve Scandilux, men også i den socialistiske bevægelse i det hele taget.

Omvendt forekommer det flamske og til dels også det hollandske parti at have videregâende ambitioner i retning af at give diskussionerne i Scandilux en bredere policy-formulerende rolle. ${ }^{19}$

Bortset fra Bruxelles-dokumentet har Scandilux dog hidtil afholdt sig fra egentlige fælles beslutninger og fastholdt karakteren af et uformelt diskussionsforum. Gruppens diskussioner har imidlertid haft en anden, mindre håndgribelig virkning, som det lange løb kan blive vigtigere end forsøg på at formulere fælles politikker. Det er fremvæksten af, hvad der bedst kan beskrives som et "fælles perspektiv" på vigtige sikkerhedspolitiske problemer. På INF-området er de oprindelige meningsforskelle blevet næsten elimineret, og i en bredere forstand er konturerne af en generel nordeuropæisk socialdemokratisk sikkerhedspolitik begyndt at aftegne sig, der på væsentlige punkter divergerer fra den NATO-politik, der hidtil har været konsensus om. Dette nye perspektiv omfatter tre hovedelementer:

1) Tankegangen om "fælles sikkerhed", således som den er fremlagt af Palmekommissionen i 1982, og som går ud på, at sikkerhedsproblemet i en situation, 
der er karakteriseret af paritet og overoprustning på kernevåbenområdet, kun kan løses gennem samarbejde med den potentielle fjende. Problemet er et fælles problem for øst og vest og kan ikke løses gennem rustning og konfrontation. "Fælles sikkerhed" vil for eksempel konkret kunne omfatte en ikkeangrebsaftale mellem NATO og Warszawa-pagten og andre tillidsskabende foranstaltninger.

2) Tankegangen om en større og mere uafhængig rolle for Vesteuropa i det fælles NATO-forsvar. Tanken er ikke at bryde de politiske og militære bånd med USA, men at de europæiske lande skal have større indflydelse på NATOs strategi og politik og bedre muligheder for at føre en selvstændig afspændingspolitik over for Sovjetunionen og Østeuropa. Inddragelse af Vesteuropa i USAs globale politik og især ideen om horisontal eskalation (det vil sige muligheden for at udvide en krig opstået i den tredie verden til NATO-området) afvises.

3) En alternativ forsvarsstrategi for Vesteuropa indeholdende følgende elementer:

a) En begrænsning af kernevåbnenes rolle i NATO-strategien, herunder en omfattende reduktion af slagmarkskernevåben og mellemdistancevåben, indførelse af en ikke-førstebrugsdoktrin for de resterende kernevåbenstyrker og etablering af kernevåbenfri zoner, både i Centraleuropa og på flankerne (Norden og Balkan);

b) modstand mod "deep strike" strategier, uanset om de baseres på avancerede konventionelle teknologier eller en blanding af nukleare, kemiske og konventionelle våben, og

c) formuleringen af en såkaldt "defensiv" koncept for forsvaret af Vesteuropa, baseret på en styrkeopbygning, der klart mangler offensive muligheder, men som stadig vil stille en angriber over for en uacceptabel risiko for, at angrebet mislykkes. Et sådant forsvar ville for eksempel kunne baseres på milits-agtige enheder udstyrede med avancerede anti-tankvåben (PGM) og bakket op af bevægelige reserveenheder i baglandet.

For øjeblikket diskuteres sådanne ideer i de fleste Scandilux-partier, tydeligst $\mathrm{i}$ SPD, som allerede har udsendt flere policy-papirer, der afspejler den nye tænkning. ${ }^{20}$ De videre implikationer af denne trend i retning af at formulere en fælles sikkerhedspolitik mellem Scandilux-partierne vil blive diskuteret i det afsluttende afsnit.

\section{Scandilux og INF-spørgsmålet}

Scandilux startede oprindelig som et forum for diskussion af en bred vifte af sikkerhedspolitiske problemer, som de mindre partier kunne forventes at blive stillet overfor inden for NATO. INF-spørgsmålet blev naturligvis opfattet som centralt, men ikke så centralt som det senere blev. Også andre spørgsmål såsom SALT/START-problematikken, MBFR-forhandlingerne i Wien, CSCE-mødet i Madrid og udsigterne for CDE-konferencen i Stockholm har været løbende diskuteret, og det samme gælder spørgsmål, som har været af mere speciel interesse for 
enkelte partier.

Det gælder for eksempel spørgsmålet om en kernevåbenfri zone i Norden. som blev aktualiseret af Arbeiderpartiet i vinteren 1980-81 og diskuteret indgående på de første to-tre møder i Scandilux. Da denne koncept kun er af specifik interesse for de nordiske partier, har den aldrig været noget centralt spørgsmål i Scandilux. men diskussionen af den kan meget vel have tjent til at introducere zone-konceptet. gøre det mere fortroligt og derigennem bane vejen for en generel accept af bredere zone-forslag såsom den kernevåbenfrie zone ned gennem Centraleuropa, som Palme-kommissionen foreslog i 1982. En anden koncept. som især nordmandene har været ivrige for at indføre i diskussionerne, er "frys"-tankegangen om en fastfrystning af supermagternes kernevăbenstyrker som indledning til en egentlig nedskæring af dem. Både fra norsk og dansk side har man kædet "frys" eksplicit sammen med INF-problematikken.

Ved Scandilux' start $\mathrm{i}$ vinteren 1980-81 var INF-spørgsmålet $\mathrm{i}$ et dødvande. I løbet af 1980 havde NATO fastsat december 1983 som deadline for den indledende INF-deployering, hvis ikke forhandlinger med Sovjetunionen forinden havde givet et tilfredsstillende resultat; det var endvidere lykkedes Helmut Schmidt at overtale Sovjctunionen til at frafalde sine forhånósbetingeiser for forhandlinger, og indledende forhandlinger mellem USA og Sovjetunionen var startet i september 1980. På den anden side kastede valget af Ronald Reagan til USAs præsident $i$ november 1980 tvivl over forhandlingernes fremtid på grund af hans manglende interesse for rustningskontrol; under alle omstændigheder måtte man forvente, at det ville tage nogen tid, før den kommende administration havde formuleret en politik på området.

På grund af Scandilux-mødernes lukkede karakter er det ikke muligt at følge udviklingen i gruppens diskussioner særlig detaljeret, men den følgende skitse gengiver i hvert fald hovedtrækkene. I løbet af 1981 blev hovedproblemet set som det at presse Reagan-administrationen til forhandlingsbordet (dette lykkedes på NATO-mødet i maj 1981) og til at formulere en realistisk forhandlingsposition. I henhold til de fleste Scandilux-deltagere har gruppens diskussioner fra første færd været præget af en dybt indgroet mistillid til Reagan-administrationens politiske hensigter; på den anden side var det $\mathrm{i}$ begyndelsen politisk nødvendigt at give den "the benefit of the doubt" og undlade en for åben kritik af dens politik, specielt fra de partier, der sad i regeringsposition og derfor havde andre kanaler for påvirkning af amerikansk politik.

Det er uklart, hvorvidt der blev diskuteret nogen specifik vestlig forhandlingsposition i Scandilux, før Reagan-administrationen i november 1981 fremlagde sin såkaldte nul-løsning (ingen vestlige opstillinger til gengæld for nedtagning af alle sovjetiske mellemdistancemissiler), der i hvert fald overfladisk syntes i overensstemmelse med ideer, som flere Scandilux-partier havde været fremme med. I begyndelsen af 1983 vendte alle Scandilux-partier sig ảbent mod denne løsning som urealistisk og til dels også urimelig. Sidstnævnte synspunkt var især fremherskende i SPD, hvis egen nul-løsning blev fremhævet som mere rimelig og realistisk, nemlig undladelse af vestlige missilopstillinger til gengæld for en væsentlig reduktion af den sovjetiske SS-20 styrke, helst ned til opstillingstallet for 1978, hvilket ville give Sovjetunionen en mindre styrke til at afbalancere Frankrigs og 
Storbritanniens kernevåbenstyrker. ${ }^{21}$

Det er højst sandsynligt, at Egon Bahr helt fra begyndelsen udtrykte sine personlige tvivl vedrørende Reagan-administrationens version af nul-løsningen. Men officielt fortsatte Scandilux-partierne med at støtte den amerikanske forhandlingsposition til langt ind i 1982. Ligeledes fortsatte de med at hilse tegn på sovjetisk fleksibilitet velkommen ud fra den grundlæggende holdning, at det gjaldt om at drive Geneve-forhandlingerne fremad og at støtte enhver bevægelse i retning af en tilnærmelse mellem synspunkterne.

Et skelsættende møde for Scandilux' INF-politik blev holdt i Bonn i januar 1983. På dette tidspunkt var alle Scandilux-partierne kommet i opposition og følte sig derfor friere til at indtage en mere uafhæengig og kritisk holdning end tidligere. De flamske og hollandske partier var nået frem til en ubetinget modstand mod opstilling af krydsermissiler $i$ deres lande og nægtede at deltage $i$ enhver regering, der ville gå med til en sádan. Det norske DNA var inde $\mathrm{i}$ den afsluttende fase $\mathrm{i}$ udarbejdelsen af et nyt, radikalt INF-program, og det danske socialdemokrati havde været inde $\mathrm{i}$ en tydelig glidning i spørgsmålet siden eftersommeren 1982. Det samme var tilfældet med SPD, men de interne uoverensstemmelser var her større end i de øvrige partier, og partiets handlefrihed var yderligere hæmmet af en kongresbeslutning i 1982 om at udsætte den endelige stillingtagen til sidst i 1983 samt af taktiske overvejelser i forbindelse med det forestående forbundsdagsvalg.

Bortset fra den stedfundne interne udvikling i partierne var der også eksterne faktorer, der kunne motivere til en skærpelse af deres INF-politik. Geneve-forhandlingerne syntes fastkørt, og den amerikanske nul-løsning havde i mere end et år mødt en konsistent sovjetisk afvisning; få dage før mødet kom de første presserapporter frem om den fejlslagne Nitze-Kvitsinski "skovturs-aftale", der yderligere øgede frustrationen over Reagan-administrationens tilsyneladende stejlhed; og endelig syntes den sovjetiske præsident Andropov i sit initiativ i december 1982 at have gjort en væsentlig indrømmelse ikke mindst til synspunkter, som SPD-talsmænd havde gjort sig til talsmænd for. ${ }^{22}$

Mødet i Bonn udviklede en konsensus, som bedst kan beskrives som et kompromis mellem SPD og de øvrige partier, og som Egon Bahr sammenfattede i 4 punkter på den efterfølgende pressekonference:

1) Nul-løsningen som fortolket af Reagan-administrationen er urealistisk.

2) USA bør nu reagere på de ægte indrømmelser, der ligger i Andropovs tilbud.

3) Geneve-forhandlingerne bør fremskyndes sigtende mod et resultat, der kombinerer en nul-løsning for NATO-siden med en betydelig reduktion af de sovjetiske INF-styrker.

4) De britiske og franske kernevåbenstyrker bør inddrages i de strategiske forhandlinger mellem øst og vest. ${ }^{23}$

På det følgende møde - i København i marts 1983 - blev der føjet yderligere tre punkter til den voksende enighed i INF-spørgsmålet. Ifølge en presserapport var der på mødet tilslutning til en fastfrysning af stormagternes strategiske kernevåbenarsenaler, en undladelse af INF-deployeringer, sålænge Geneve-forhandlingerne fortsatte, samt en forlængelse af NATOs deadline, hvis det skulle blive 
nødvendigt for at skabe en forhandlingsløsning. ${ }^{24}$

Bestræbelserne for at nă frem til en fælles politik i INF-spørgsmălet kulminerede på mødet $\mathrm{i}$ Bruxelles i oktober 1983. hvorfra der blev udsendt en detaljeret erklæring. Denne opfordrede blandt andet til en officiel genvurdering af forhandlingssituationen inden for NATO, inden INF-opstillingen blev indledt, gik ind for en forlængelse af Geneve-forhandlingerne ind i 1984, opfordrede til en ensidig sovjetisk INF-nedskæring samt en udsættelse af de vestlige deployeringer, "der kan ødelægge de elementer af fremskridt, der allerede er nået". Erklaringen fremførte, at en rakke omstandigheder var andret siden 1979, der kunne berettige en forlængelse af forhandlingerne, og gik desuden ind for, at de franske og britiske kernevåbenstyrker blev inddraget $\mathrm{i}$ disse. ${ }^{25}$

Bruxelles-erkleringen betød ikke i sig selv ct definitivt nej til de forestående NATO-deployeringer; dette måtte vente til efter SPDs ekstraordinare kongres $\mathrm{i}$ november 1983. Men den fremlagde alle præmisserne for en afvisning, og dette blev da også den linie, alle partierne (med undtagelse af PS) indtog, da deployeringerne begyndte i december 1983. Kun de danske socialdemokrater var imidlertid på grund af de specielle parlamentariske forhold under firkløverregeringen $\mathrm{i}$ stand til at påvirke deres lands officielle politik - uden at det dog fik nogen virkning på NATOs politik. Samtidig med at det lykkedes Scandilux at formulere en fælles, sammenhængende politik på INF-området, afsløredes også gruppens afgørende svaghed: de deltagende partiers mangel på reel magt og indflydelse.

\section{Indflydelsesmgnstre i Scandilux}

Selv om Scandilux ikke bevidst har sigtet mod formuleringen af beslutninger og politikker, blev der alligevel skabt en vidtgående enighed i INF-spørgsmålet, og som nævnt er der tegn på, at en bredere konsensus om væsentlige aspekter af vesteuropæisk sikkerhedspolitik vil kunne skabes. Hvorledes har indflydelsesrelationerne været $\mathrm{i}$ denne proces, og hvorledes har tendensen i retning af konsensus påvirket de enkelte partiers politik?

Der er blandt deltagerne i Scandilux enighed om, at Egon Bahr er den dominerende person i gruppen. Denne position har hvilet på tre elementer: 1) Information om den interne sikkerhedspolitiske debat i SPD, 2) information om og evaluering af amerikansk og (især) sovjetisk INF-politik, og 3) hans analyse af den politisk-strategiske situation og mulige policy-alternativer.

Internt i SPD har Bahr været en ledende kraft i den proces, der førte til partiets nej til INF-deployering i slutningen af 1983 og til en justeret sikkerhedspolitik på partikongressen i Essen i maj 1984. Scandilux' rolle i denne proces har givetvis været ganske begrænset $i$ forhold til de parti-interne faktorer; man kan dog antage, at Bahr har haft to interesser for øje: For det første at koordinere (og det vil sige styre) udviklingen i Scandilux med tendensen i SPD, således at SPD ikke isoleredes $\mathrm{i}$ Scandilux, og for det andet at lade Scandilux fungere som et slags lokomotiv $\mathrm{i}$ den interne SPD-debat ved at holde gruppen en smule foran SPD. Det er herunder lykkedes Bahr at få en række af sine synspunkter og vurderinger accepteret af Scandilux, for eksempel hans positive vurdering af fleksibiliteten i sovjetisk INF- politik, kravet om, at de britiske og franske kernevåbenstyrker skal 
inddrages i INF-forhandlingerne, og argumentet om, at Geneve-forhandlingerne burde forlænges ud over 1983 for at kompensere for, at de først kom i gang i slutningen af 1981, det vil sige med to års "forsinkelse" $\mathrm{i}$ forhold til dobbeltbeslutningen. Bahrs briefinger om den aktuelle situation har også haft konkrete politiske virkninger, der sikkert ikke har været utilsigtede, for eksempel hans oplysninger på Bruxelles-mødet i oktober 1983 om, at Pershing II- og krydsermissilerne allerede ville ankomme til Europa lige efter forbundsdagens godkendelse af deployeringen, der var med til at udløse beslutningerne på Bruxelles-mødet såvel som efterfølgende nationale initiativer fra deltagerpartiernes side.

Alligevel er det ikke helt korrekt at opfatte Scandilux som "Bahr's klub". Selv om Bahr personligt har arbejdet for radikale ændringer i den europæiske INF- og sikkerhedspolitik, har han samtidigt været repræsentant for et parti, hvor den interne debat om INF-spørgsmålet har været særlig intens, og hvor loyaliteten over for dobbeltbeslutningen og NATO's generelle politik har været mere udtalt end $\mathrm{i}$ de fleste andre partier. Hvor det gælder formuleringen af specifikke positioner, har andre partier ofte kunnet spille en initierende rolle. For eksempel formulerede det norske Arbeiderparti i januar 1983 et såkaldt raketprogram, hvorfra adskillige synspunkter efterhånden blev "godkendt" inden for Scandilux, men som på sin side i hvert fald delvis var inspireret af Scandilux-drøftelserne. ${ }^{26}$ Scandilux er således karakteriseret ved et indviklet, dynamisk samspil mellem Bahr som SPDs repræsentant og de mindre partier, hvor det kan være vanskeligt at udrede, hvem der påvirker hvem.

Det er ikke muligt her at gå ind på Scandilux' indflydelse på alle de deltagende partier, men der vil blive gjort et forsøg på at illustrere indflydelsen på et enkelt parti, nemlig det danske socialdemokrati. Generelt kan Scandilux' betydning for de deltagende partier sammenfattes i fire aspekter.

Det vigtigste er sandsynligvis Scandilux' rolle som kilde til information, politisk analyse og policy-optioner for deltagerpartierne. Selv om de små Scandilux-partier varierer ganske meget med hensyn til organisatoriske ressourcer, så har de alle begrænsede muligheder for at skaffe sig og bearbejde relevant sikkerhedspolitisk information; kun et par af partierne har et organisationsapparat samt den nødvendige interne motivation til at gennemføre en kontinuerlig sikkerhedspolitisk analysevirksomhed, der kan forsyne partiledelsen med underbyggede policyalternativer. Deltagelse i Scandilux åbner således en "genvej" til en begrundet politisk position for partier med svagtudviklede analytiske ressourcer, og det er alt andet lige - formentlig disse partier, der er blevet stærkest influeret af Scandilux.

For det andet har Scandilux påvirket tempoet $\mathrm{i}$ den politiske ændringsproces $\mathrm{i}$ de enkelte partier. I en proces, hvor alle deltagende partier med undtagelse af PvdA har bevæget sig fra forskellige grader af støtte til dobbeltbeslutningen til (næsten) total modstand mod dens gennemførelse, har takten i udviklingen af standpunkter i hvert fald $\mathrm{i}$ visse tilfælde været bestemt af ønsket om at holde trit med de øvrige partier. Alt $\mathrm{i}$ alt har Scandilux formentlig bidraget til at $\emptyset g e$ ændringstakten i deltagerpartiernes politik, men der kan også findes eksempler på, at hensyn til enkelte partier, især SPD, har haft en bremsende effekt.

For det tredie har Scandilux været en vigtig legitimerende faktor for de sted- 
fundne ændringer $\mathrm{i}$ deltagerpartiernes politik. Disse andringer har mødt såvel intern modstand i partierne som kritik og pres fra de borgerlige partier og regeringer, herunder også ikke mindst Reagan-administrationen i USA. I denne situation har den legitimerende effekt af ikke at stå isoleret, men at vare led i en bredere tværnational ændringsproces spillet en vigtig rolle for de mindre partier.

For det fjerde har Scandilux øget de deltagende politikeres status og indflydelse i de hjemlige partidiskussioner. Scandilux er en yderst elitar "klub", hvis "medlemmer" vaerdsatter deres "medlemskab" højt, băde fordi det i sig selv indebarer intellektuelle og sociale bonus-effekter, og fordi det giver prestige og indflydelse hjemme. Deltagelse i Scandilux-møderne giver deltagerne kontrol over vigtige eksterne input i den hjemlige beslutningsproces og giver samtidig også en personlig tilskyndelse til at søge disse inputs omformet til politik på det nationale plan.

For det danske socialdemokratis vedkommende har alle disse generelle faktorer spillet en rolle. Socialdemokratict har færre organisatoriske ressourcer på det sikkerhedspolitiske felt end de øvrige Scandilux-partier, og den sikkerhedspolitiske diskussion i såvel vælger- som parlamentsparti er begrænset. Bl.a. derfor har Scandilux formentlig betydet mere for udviklingen af Socialdemokratiets politik end for andre deltagerpartier. De to politikere, der har gået $\mathrm{i}$ spidsen $\mathrm{i}$ ændringsprocessen, Lasse Budtz og Kjeld Olesen, har begge deltaget regelmæssigt i Scandilux og har kontinuerligt henvist til udviklingen i de øvrige socialdemokratiske partier som legitimering af ændringerne i partiets egen holdning; også Anker Jørgensen siges at være blevet stærkt påvirket af diskussionen på de møder, han har deltaget i. Endelig kan ændringstakt og -retning i Socialdemokratiets INFpolitik ses som en afspejling af udviklingen i Scandilux' INF-politik.

Som i andre partier startede Socialdemokratiets reorientering i første halvdel af 1982 og accelererede så kraftigt efter overgangen til opposition i september 1982. Men i modsætning til de fleste andre Scandilux-partier, der kom i opposition i disse år, bevarede det danske parti grebet om udenrigspolitikken gennem en alliance med venstrefløjspartierne og de radikale. Socialdemokratiet har derfor haft andre muligheder for at påvirke den officielle politik end de øvrige Scandiluxpartier, og det har givet partiet en potentiel rolle som "frontspids" eller "prøveklud" for Scandilux-politikken. Der er ingen indikationer af, at de andre partier åbent har prøvet at påvirke partiets politik, men under alle omstændigheder har de fulgt det danske "eksperiment" med stor interesse.

Det første væsentlige skridt $\mathrm{i}$ ændringen af partiets politik, standsningen af yderligere bevillinger til INF-projekter pả NATOs infrastrukturprogram i efteråret 1982 var mere eller mindre direkte inspireret af et tilsvarende krav fremsat af DNAs ledelse. Det næste skridt, en tale, hvori Kjeld Olesen i januar 1983 fremlagde et "program", der - tilsigtet eller ikke - kom til at blive et "blueprint" for udviklingen af partiets politik i 1983, havde en mere kompliceret baggrund. "Programmet" bestod af 10 punkter:

1) Fastfrysning af eksisterende kernevåbenarsenaler;

2) Reagan-regeringens nul-løsning er uacceptabel;

3) USA bør følge Andropovs tilbud op med en egen indrømmelse;

4) ingen deployering af vestlige INF-missiler, "hvilket forudsætter en yderligere 
reduktion af SS-20";

5) de franske og britiske missiler må tælles med i forhandlingerne;

6) forhandlingerne må forlænges ud over 1983 om nødvendigt;

7) ingen deployeringer, mens der forhandles;

8) hvis USA og Sovjetunionen enes om en begrænset opstilling, vil partiet tage stilling på det nye grundlag;

9) efter en INF-aftale må der forhandles videre om kernevåbenfrie zoner;

10 ) intensivering af forhandlingerne om de konventionelle våben. ${ }^{27}$

De ti punkter blev fremsat umiddelbart efter Scandilux-mødet i Bonn i januar 1983 og fremlæggelsen af DNAs såkaldte raketindstilling. Det er derfor nærliggende at lede efter inspirationen til dem her. Sammenfaldet af pkt. 2-5 med de fire punkter på Bahrs liste (se ovenfor) er helt åbenbar, men der er også tydelig inspiration fra det norske program, bl.a. ved understregningen af fastfrysningstankegangen og af behovet for forhandlinger ud over 1983-fristen uden deployering samt henvisningerne til atomfrie zoner og konventionel nedrustning.

Mens Arbeiderpartiets raketprogram og efterfølgende kursændring i spørgsmålet $\mathrm{i}$ høj grad hvilede på interne præmisser, er det sandsynligt, at den tilsvarende proces i Socialdemokratiet var mere eksternt påvirket, og $\mathrm{i}$ den forbindelse indtager Scandilux-mødet i Bonn i januar 1983 formentlig en central placering. I løbet af 1983 udmøntedes punkterne i Kjeld Olesens "program" gradvis i partiets politik og gennem diverse dagsordener $\mathrm{i}$ folketinget - og i hvert fald delvis koordineret med udviklingen i Scandilux. I februar 1983 vedtog folketinget en dagsorden rummende pkt. 1-3 på Bahrs liste, og i maj 1983 omfattede en ny dagsorden de tre nye krav, som man var enedes om på Scandilux-mødet i marts, dvs. fastfrysning, ingen deployering, mens der forhandles, og forlængelse af forhandlingerne om nødvendigt såvel som det "gamle" Scandilux-krav om inddragelse af de britiske og franske styrker i INF-forhandlingerne. I det videre forløb blev anbefalingerne fra mødet $\mathrm{i}$ oktober fulgt op i november af en dagsorden, der krævede en politisk nyvurdering i NATO, inden INF-missilerne blev opstillet, og endelig blev regeringen i december pålagt at tage klar afstand i NATO-rådet fra den begyndende deployering. Danmark blev således det eneste Scandilux-land, hvor den konsensus, der etableredes i gruppen, kunne omformes til officiel politik - hvor meget det end var i modstrid med Schlüter-regeringens ønsker og politiske instinkter.

I Danmark demonstreredes samtidig en vigtig sideeffekt af Scandilux-samarbejdet, nemlig sammenbruddet af den traditionelle sikkerhedspolitiske konsensus, som indtil begyndelsen af 1980'erne var herskende i alle Scandilux-lande (med undtagelse af Storbritannien) og i Vesteuropa som helhed. Ved udgangen af 1983 var denne konsensus brudt ned eller stærkt truet i alle lande, i hvert fald på INFområdet. Et væsentligt spørgsmål til fremtiden var, om dette sammenbrud af den brede enighed ville brede sig til andre politik-områder, eller om konsensus på lidt længere sigt kunne genetableres i de enkelte lande og på vesteuropæisk plan.

\section{Quo Vadis, Scandilux?}

NATO-beslutningen om at indlede INF-deployeringen var ikke blot et alvorligt 
politisk tilbageslag for Scandilux: den stillede ogsa gruppen over for vanskelige organisatoriske problemer. 1 gruppens første tre år havde INF-spørgsmålet - med den indbyggede deadline december 1983 - givet struktur og konsistens til de ellers informelle og frit flydende diskussioner $\mathrm{i}$ gruppen $\mathrm{og}$ forlenet dem med betydning, ja endog givet dem en presserende karakter. INF-deployeringen betød naturligvis ikke, at spørgsmålet ophørte med at være politisk relevant, men det mistede helt klart sin politiske vægt og dermed ogsá evnen til at være det samlende element $\mathrm{i}$ Scandilux.

Scandilux-partiernes nej til INF-deployeringen aktualiserede desuden risikoen for yderligere splittelse mellem nord og syd $\mathrm{i}$ den socialdemokratiske bevagelse og for et egentligt sammenbrud af den traditionelle sikkerhedspolitiske konsensus med de borgerlige partier i Vesteuropa.

I denne situation aftegner der sig mindst tre spørgsmâlstegn vedrørende Scandilux' fremtid:

For det første: bør Scandilux fortsætte i sin nuværende form som et fælles forum for de små nordvesteuropæiske partier og SPD? Bortset fra nogle regerende sydeuropæiske partiers jalousi og risikoen for at uddybe nord-syd modsætningerne kan der fremføres andre og vasentlige argumenter for en vis opblødning af Scandilux' eksklusive karakter. Såfremt der i de kommende år skal udvikles en fælles vesteuropæisk sikkerhedspolitik, vil det franske socialistparti indtage en nøglestilling; hverken på parti- eller statsniveau kan der udvikles en levedygtig og realistisk politik uden om PS.

Det er i den forbindelse uden videre klart, at Scandilux i sin hidtidige form ikke kan fungere som ramme for udviklingen af, hvad der i praksis vil være et kompromis mellem SPD og PS. På den anden side er udsigterne til en ægte tilnærmelse mellem de to partier så usikre til trods for den indtrådte atmosfæriske forbedring, at dette hensyn næppe kan være et vægtigt argument mod en fortsættelse af Scandilux - rent bortset fra, at adskillige af gruppens medlemmer sandsynligvis ville være stærkt betænkelige ved indholdet af et sådant kompromis. ${ }^{28}$ Deltagerpartierne går i øjeblikket ind for en fortsættelse af Scandilux i den hidtidige form, og selv PS syncs at have upgive nogie aí sine reservationer over for den; gruppen synes derfor at ville fortsætte på basis af "likemindedness". Dette betyder ikke, at der ikke kan være argumenter for at søge at dæmpe den skepsis, som Scandilux har skabt bl.a. i Sydeuropa, f.eks. ved at indlede et nærmere, delvis formaliseret samarbejde med partierne der. En anden åbning, der kan rumme visse perspektiver, er til partier i Østeuropa. Bl.a. har PvdA haft kontakter til det ungarske kommunistparti herom, og det diskuteres for øjeblikket, hvilken rolle Scandilux kan spille i denne forbindelse.

For det andet: bør Scandilux' format ændres nu, hvor der ikke længere er INFspørgsmålet til at give gruppens diskussioner struktur og kontinuitet? Hvis man bortser fra den mulighed, at et nyt emne kan trænge sig på med en sådan vægt, at det kan blive en naturlig fokus for diskussionerne, er der risiko for, at disse kan blive reduceret til relativt udsigtsløs "hyggesnak", hvis den hidtidige ret løse koncentration om "den aktuelle situation" bliver fortsat. Der er givetvis behov for en vis strukturering af debatten, herunder også en vis planlægning af diskussionsemner, hvis dynamikken i gruppens forhandlinger skal bevares; på den anden 
side rejser dette faren for, at den hidtidige frie og utvungne debatform bliver hæmmet.

Der kan som nævnt allerede spores en øget forståelse for behovet for en regulær dagsorden for Scandilux-møderne. En anden tendens går $\mathrm{i}$ retning af at centrere diskussionen omkring formelle papirer, ikke nødvendigvis med henblik på enighed om specifikke formuleringer, men for at give denne en vis struktur og substans. Hvis en sådan tendens skulle udvikle sig videre, kunne Scandilux på den måde udvikle sig til en slags avanceret akademisk europæisk studiegruppe i sikkerhedspolitik.

Dette er imidlertid næppe, hvad de travle og pragmatisk politikere, der samles i Scandilux, forestiller sig. For fortsat at være interessante, må diskussionerne $\mathrm{i}$ gruppen bevare et kraftigt og visibelt element af umiddelbar politisk relevans og angå emner og problemer, som deltagerne møder $i$ deres politiske hverdag med at formulere sikkerhedspolitiske standpunkter. En løsning, der kunne styre fri af såvel Scylla, en betydningsløs konversationsklub, og Charybdis, en akademisk studiegruppe, kunne være en model, der kombinerer diskussionen af den løbende, aktuelle situation med en bevidst bestræbelse for at udvikle, ikke en fælles politik, men et fælles perspektiv på de mangfoldige problemer, som medlemspartierne vil blive stillet over for stillingtagen til på det sikkerhedspolitiske område $\mathrm{i}$ de kommende år.

Dette rejser det sidste og vigtigste spørgsmål vedrørende Scandilux' fremtid: Hvad bør være gruppens fremtidige politiske orientering? Det har ovenfor været postuleret, at et såkaldt fælles perspektiv begynder at aftegne sig blandt Scandilux-partierne centreret om begrebet "fælles sikkerhed", tanken om en europæisering af forsvaret af Vesteuropa og ideen om et denukleariseret og defensivt orienteret forsvar.

Der er endnu ikke nogen egentlig konsensus mellem Scandilux-partier om disse koncepter eller deres økonomiske og politiske implikationer, og i det hele taget trænger de til en grundig politisk analyse, før de kan omformes til konkrete, "operative" sikkerhedspolitiske optioner. Hvad indebærer f.eks. det samarbejde mellem modstående parter, der i Palme-kommissionens opfattelse indgår i begrebet fælles sikkerhed?

Europæiseringsproblematikken er endnu vanskeligere at håndtere, og målsætningen om en større vesteuropæisk rolle i det vestlige forsvar har vel næppe endnu hævet sig meget op over det politiske slogans niveau. Uanset den udbredte aversion i Scandilux-partierne mod den nuværende amerikanske politik i og uden for NATO står de konsekvenser, det er muligt og ønskeligt at drage heraf, uklart for de fleste af dem. I flere af partierne er der således stærke atlantiske fløje, som vil være betænkelige ved en for stærk understregning af det europæiske element. F.eks. måtte et diskussionspapir til SPD-kongressen i Essen i maj 1984, der stærkt betonede europæiseringsmålsætningen, revideres betydeligt under pres fra partiets atlantikere. Det norske Arbeiderparti står i en lignende problemstilling, der skærpes af, at europæisering for Norge meget let kan blive lig med "centraleuropæisering", dvs. en koncentration af interessen omkring det centraleuropæiske teater og dermed en sikkerhedspolitisk marginalisering af Norge, som norske politikere hidtil har været opsatte på at undgå. DNA's Europa-udvalg har ganske 
vist i sommeren 1984 anbefalet en norsk tilknytning til WEU - Den vesteuropæiske Union - og gået ind for et mere ligevagtigt forhold mellem Vesteuropa og USA og et øget europæisk samarbejde om sikkerhed og forsvar, ${ }^{29}$ men der er givetvis grænser for. hvor starkt DNA kan fravige sin hidtidige atlantisk orienterede politik. Også i det danske socialdemokrati har europæiseringsproblemet skabt problemer, fordi det uundgåeligt bliver indblandet i den vanskelige interne debat om de politiske granser for EF-medlemskabet. Problemet set fra et dansk socialdemokratisk synspunkt er både risikoen for marginalisering og for en tattere tilknytning til den sikkerhedspolitiske problematik i Centraleuropa, f.eks. i det tilfælde WEU skulle blive kernen i et kommende europæisk forsvarssamarbejde. Mens f.eks. en af de de centrale skikkelser i Scandilux, hollænderen Klaas de Vries, kan hilse genoplivelsen af WEU velkommen som en "fortræffelig idé", var de oprindelige danske reaktioner yderst forbeholdne; ${ }^{30}$ efterhånden er signalerne dog gradvis blevet mere positive. ${ }^{31}$

Europæisering er således et tvetydigt symbol, der ikke blot sætter fokus på Scandilux-partiernes falles interesser, men også på potentielle divergenser i synet på, hvor langt og hvordan den kan realiseres. Det samme gælder adskillige elementer i det "nye perspcktivs" militar-stratcgiske indhold. De danske og norske partier interesserer sig væsentligt mere for problematikken omkring kernevåbenfrie zoner end partierne i Centraleuropa, hvor problemet er den massive tilstedeværelse af kernevåben $\mathrm{i}$ deres lande og ikke perfektioneringen af en af de facto kernevåbenfrihed. For SPD og partierne i Benelux vil problemer som ikke-førstebrug, reduktion af kernevåbnenes rolle i NATO-strategien, og konventionalisering af såkaldt "dual-capable" våben stå i forgrunden og have større øjeblikkelig relevans end zoneproblematikken. Ligeledes kan man argumentere, at konceptet om omrustning til et defensivt forsvar har - om nogetsteds - en større relevans på NATOs centralafsnit end i Nordregionen, hvor det med den herskende styrkestruktur kun har begrænset mening.

Det "nye" socialdemokratiske perspektiv er endnu kun en skitseagtig konception, der desuden potentielt indebærer visse interesseforskelle mellem de nordlige og centraleuropeiske partier i Scandilux. Hvorvidt perspektivet kan udvikles til et egentligt fælles sikkerhedspolitisk program, afhænger dog ikke blot af, om politikerne i Scandilux er villige til at opgive noget af deres hidtidige ad hoc-prægede arbejdsmetode til fordel for et mere langfristet og målrettet perspektiv $i$ gruppens arbejde. Det afhænger også af, hvor langt de deltagende partier vil være interesserede $\mathrm{i}$ at udvikle en sådan eksklusiv Scandilux-koncept, der vil kunne vanskeliggøre konsensusdannelsen på nationalt og europæisk plan såvel som inden for den socialdemokratiske bevægelse i bredere forstand. Også overvejelser over et sådant programs indvirkning på mulighederne for at vende tilbage til regeringsmagten og genopnả reel indflydelse på europæisk sikkerhedspolitik vil spille ind. Som i næsten alle spørgsmål, der vedrører Scandilux, er det også her SPD, der vil kunne lægge det afgørende lod i vægtskålen. 


\section{Noter}

1) Artiklen er en omredigeret og lettere forkortet udgave af The Scandilux Experiment: Towards a Transnational Social Democratic Security Perspective?. Paper prepared for the workshop on "Social Democracy and Defence", ECPR Joint Sessions of Workshops, Salzburg, April 13-18, 1984.

2) I denne artikel anvendes overalt benævnelsen "socialdemokratisk" om partier, der deltager i Scandilux-samarbejdet, selv om flere af partierne betegner sig selv som socialistiske. Det samme galder generelt ved omtalen af partier, der er medlem af Socialistisk Internationale.

3) Jfr. Jacob A. Buksti \& Hans Martens, "Interesseorganisationer i EF. Europaorganisationernes rolle og betydning for danske interesseorganisationer i EF-politikken", i Chr. Thune \& Nikolaj Petersen, red., Dansk Udenrigspolitisk Årbog (herefter DUÅ) 1983, København 1984, pp. 61-93.

4) Geoffrey and Pippa Pridham, Transnationalism, Party Co-operation and European Integration. London, 1981, pp. 2-3.

5) Følgende personer er interviewet $\mathrm{i}$ forbindelse med undersøgelsen: Oscar Debunne (international sekretær, BSP), Bernard Tuyttens og Rik Coolsaet (forskere ved SEVI, BSP's udredningsinstitut), Klaas de Vries (sikkerhedspolitisk ordfører, PvdA), Joop den Uyl (formand, PvdA, tidligere ministerpræsident), Maarten van Traa (international sekretær, PvdA), Lasse Budtz (udenrigspolitisk ordfører, SD), Kjeld Olesen (tidligere udenrigsminister, SD), Steen Christensen (international sekretær, nu partisekretær, SD), Einar Förde (næstformand, DNA), Thorbjørn Jagland (international sekretær, DNA), Egon Bahr (MdB m.v., SPD), Hans-Eberhard Dingels og Veronika Isenberg (internationale sekretær, SPD), Mike Gapes (forsker, Labour) og Jacques Hunzinger (international sekretær, PS). Det understreges, at vurderingerne $\mathrm{i}$ artiklen er mine egne og ikke kan tilskrives nogen af de interviewede.

6) Jfr. Reimund Seidelmann, "Die Sozialistische Internationale als Parteienbewegung und politischer Wegbereiter", Europa-Archiv, 21/1981, pp. 659-68; Zdenek Hejzlar, "Venter en ny æra - eller har Socialistisk Internationale overlevet sig selv?", $\mathrm{Ny}$ Politik, 14. årg. nr. 7 (juli 1983), pp. 21-29; David Hanley \& Hugues Portelli, L'Internationale Socialiste et le désarmement: limites et possibilités d'une diplomatie socialdemocrate. Paper til workshop om "Social Democracy and Defence", ECPR Joint Sessions of Workshops, Salzburg, April 13-18, 1984; Ole Karup Pedersen, "Socialistisk Internationale, Socialdemokratiet og dansk udenrigspolitik", Økonomi og Politik, 1983 , nr. 4, pp. 301-08.

7) De andre to punkter var menneskerettigheder og den nye økonomiske verdensorden. Socialist Affairs, vol. 27 (1977), pp. $5 \mathrm{ff}$.

8) Conference on Security and Disarmament. March 19 and 201981 , Paris. Confederation of the Socialist Parties of the E.C., 1981. Jfr. History of the Confederation. Confederation..., n.d.; Norbert Gresch, "Der Bund Sozialdemokratischer Parteien in der EG", i Gerhard Hiersch \& Raimund Seidelmann (eds.), Eurosozialismus. Die demokratische Alternative. Köln, 1979, pp. 132-44.

9) Manifesto of the Confederation of the Socialist Parties of the European Community, adopted the XIIIth Congres of the Confederation, Luxembourg, March 9th 1984.

10) Common Security. A Programme for Disarmament. The Report of the Independent Commission on Disarmament and Security Issues under the Chairmanship of Olof Palme. London 1983.

11) Jfr. Nikolaj Petersen, "The Alliance Policies of the Smaller NATO Countries", i L. S. Kaplan \& R. W. Clawson, eds., NATO After Thirty Years. Wilmington, Del., 1981, pp. 83-106; Anthony J. Dolman, "The Like-Minded Countries and the New International Order: Past, Present and Future Prospects", Cooperation and Conflict, XIV (1979), pp. 57- 85.

12) Når også det wallonske parti blev inddraget som medindbyder, skyldtes det sikkert et ønske om ikke at uddybe divergenserne mellem de to partier i INF-spørgsmålet.

13) Brev fra Karel van Miert til Willy Brandt 12. januar 1981.

14) Efter valgnederlaget i 1983 har Labour søgt at slå ind på en mere midtsøgende kurs, 
delvis inspireret af Scandilux. Se f.eks. Defense \& Security for Britain. Statement to Annual Conference by the National Executive Committee. Labour Party 1984.

15) I december 1983 indledte PS og SPD en række bilaterale møder med henblik på at diskutere sikkerhedspolitiske spørgsmål. Møderne har ført til en væsentlig forbedring af atmosfæren mellem de to partier, og en øget forstáelse af deres respektive positioner, men nappe til en ændring af disse.

16) Det norske DNA mistede regeringsmagten i september 1981, dernæst fulgte de to belgiske partier (december 1981). PvdA (maj 1982) og SPD og Socialdemokratiet. begge i september 1982.

17) PASOK (Grakenland) og PS dannede regering i lobet af 1981, det spanske PSOE i 1982 og de italienske og portugisiske partier i 1983.

18) Hvert parti sender normalt 3 reprasentanter til møderne. De faste danske deltagere er Lasse Budtz, Kjeld Olesen og Steen Christensen, men Anker Jørgensen har også deltaget i flere møder. Repræesentanterne er relativt højt placerede som partiledere (f.eks. Karel van Miert, (BSP). Joop den Uyl (PvdA). Gro Harlem Brundtland (DNA) og Neil Kinnock (Labour)), tidligere ministre, gruppeformænd eller sikkerhedspolitiske ordførere (f.eks. Louis Tobback (BSP), Ernest Glinne (SPB), Klaas de Vries (PvdA), Thorvald Stoltenberg (DNA) og Egon Bahr (SPD)). Endvidere sender alle partier deres internationale sekretærer til møderne.

19) F.eks. havde den "europæiske sikkerhedsplan", som det flamske parti fremlagde i efteråret 1983 karakter af et slags udkast til en bredere fælles Scandilux-sikkerhedspolitik. Se Karel van Miert, Louis Tobback, Rik Coolsaet \& Bernard Tuyttens, Uit de waanzin. Een veiligheidsplan voor Europa. Brussel (SEVI) 1983.

20) Se f.eks. Kriegsverhinderung im Atomzeitalter. Rapport fra SPDs arbejdsgruppe om "Neue Strategien" (SPD juli 1983); Horst Ehmke, Uberlegungen zur Selbstbehauptung Europas. Ein Diskussionspapier (SPD jan. 1984); Friedenspolitik. Für eine neue Strategie des Bündnisses. Antrag des Parteivorstandes für den SPD-Parteitag in Essen im Mai 1984 (SPD jan. 1984); Andreas von Bülow, Gedanken zur Weiterentwicklung der Veteidigungsstrategien in West und Ost (SPD jan. 1984); Uit de Waanzin, op.cit. (BSP sept. 1983); Rik Coolsaet, The "Conventionalization" of NATO's Military Strategy, (BSP marts 1984); Vrede en Veiligheid. Een nota van de Tweede Kamerfractie Partij van de Arbeid (PvdA maj 1984); Defence and Security for Britain (Labour 1984). Enkelte formuleringer har også $\mathrm{i}$ ret summarisk form fundet vej ind $\mathrm{i}$ det nye socialdemokratiske arbejdsprogram vedtaget på partikongressen i september 1984 .

21) Se f.eks. interview med Egon Bahr i Der Stern 21. juli 1983.

22) Om udviklingen i INF-spørgsmålet se Ib Faurby, Hans-Henrik Holm \& Nikolaj Petersen, "Indledning: INF-spsrgsmålets historie og implikationer", i Hans-i ienrik Holm \& Nikolaj Petersen, red., Slaget om missilerne. Dobbeltbeslutningen og sikkerheden $i$ Europa. Århus 1983, pp. 9-44.

23) Arbeiderbladet (Oslo) 15. januar 1983.

24) International Herald Tribune 18. maj 1983.

25) Press conference document presented by Karel van Miert, Bruxelles 21.-22. oktober 1983. Dokumentet er optrykt som appendiks til mit ECPR-paper, se note 1.

26) Se indstilling til DNAs landsmøde 1983 fra partiets internationale udvalg, jan. 1983: Landsmøtehefte 1 A. Forslag til nedrustningsplan. Oslo 1983.

27) Se $D U \AA ̊ 1983$, pp. 216-17.

28) Der er nok et udbredt ønske $i$ gruppen om at inddrage PS $i$ konsensus, men samtidig ringe vilje til at imødekomme de franske synspunkter, som mange deltagere finder "uforståelige" og paradoksale.

29) Politiken, 13. juli 1984.

30) Weekendavisen 22.-28. juni 1984. Smst. udtalte Lasse Budtz: "I dag er WEU milevidt fra det danske socialdemokratis holdning, for det er højreorienteret og meget militaristisk, og man taler kun om afskrækkelse, ikke om afspænding. Men WEU skal sandelig også bruges til detente og afspænding".

31) Se f.eks. Anker Jørgensens og Lasse Budtz' taler på partikongressen i sept. 1984. Politiken, 17. sept. 1984. 